\title{
Peripheral neuropathy in a copper-deficient goat
}

\author{
Valdir Morais de Almeida ${ }^{1}$ Hisadora Advincula da Silva Chaves ${ }^{2}$ Givaldo Bom da Silva Filho ${ }^{2}$ \\ Danielle Pimentel Ribeiro ${ }^{2}$ Thaiza Campelo Braga ${ }^{2}$ Fábio de Souza Mendonça ${ }^{2 *}$
}

${ }^{1}$ Programa de Pós-graduação em Medicina Veterinária, Departamento de Medicina Veterinária, Universidade Federal Rural de Pernambuco (UFRPE), Recife, PE, Brasil.

${ }^{2}$ Laboratório de Diagnóstico Animal, Departamento de Morfologia e Fisiologia Animal, Universidade Federal Rural de Pernambuco (UFRPE), 52171- 900, Rua Dom Manoel de Medeiros, s/n, Dois Irmãos, Recife, PE, Brasil. E-mail: fabio.mendonca@pq.cnpq.br. "Corresponding author.

\begin{abstract}
This report aimed to describe a case of peripheral neuropathy in a copper-deficient goat, and highlights the clinical, and pathological features of the disease. The goat had low body score, hyporexia, alopecia, achromotrichia, left hindlimb protraction, paralysis with dragging of digit and difficulty to stand up and microcytic normochromic anemia. Copper concentration in serum was markedly lower $\left(2.0 \mu \mathrm{mol} \mathrm{L}^{-1}\right)$ whereas the iron serum content was significantly increased $\left(51.0 \mu \mathrm{mol} \mathrm{L}^{-1}\right)$. The main gross alteration was the reduction of the quadriceps vastus laterallis muscle volume. Histologically, there was atrophy of the quadriceps vastus laterallis muscle and presence of satellite cells, infiltration of lymphocytes, macrophages and replacement of the fibers by connective tissue. In the femoral nerve, there was axonal degeneration with myelin sheath expansion and presence of vacuoles, usually in chains and containing axonal debris or macrophages. Clinical, laboratorial and pathologic findings are consistent with peripheral neuropathy due to a severy copper deficiency.

Key words: mineral deficiency, paralysis, monoplegia, muscular atrophy, ruminants.
\end{abstract}

Neuropatia periférica em caprino com deficiência de cobre

RESUMO: Este trabalho tem como objetivo descrever um caso de neuropatia periférica em um caprino com deficiência de cobre e destaca as características clínicas e patológicas da doença. O caprino apresentava baixo escore corporal, hiporexia, alopecia, acromotriquia, protração do membro posterior esquerdo, com arrastar de pinça do membro posterior, dificuldade para se levantar e anemia microcítica normocrômica. A concentração sérica de cobre estava significantemente baixa $\left(2.0 \mu \mathrm{mol} \mathrm{L}^{-1}\right)$, enquanto a concentração de ferro estava alta $\left(51.0 \mu \mathrm{mol} \mathrm{L}^{-1}\right)$. O principal achado de necropsia consistiu em redução do volume do músculo quadríceps vasto lateral. Histologicamente, havia atrofia do músculo quadríceps vasto lateral, infiltrado linfocítico, presença de células satélites, macrófagos e substituição das fibras musculares por tecido conjuntivo. No nervo femoral, havia degeneração axonal com dilatação da bainha de mielina e presença de vacúolos, geralmente em cadeia, contendo, ocasionalmente, restos axonais ou macrófagos. Os achados clínicos, laboratoriais e patológicos são compativeis com neuropatia periférica devido à deficiência severa de cobre.

Palavras-chave: deficiência mineral, paralisia, monoplegia, atrofia muscular, ruminantes.

Copper is a trace metal which acts in several activities of numerous enzymes and is thus essential for the structure and function of the immune system, bone marrow and nervous system (COUSINS et al., 1985). Copper deficiency in ruminants results from a defect in copper metabolism or the absorption and use of copper in the body. In adult sheep, goat and cattle, copper deficiency is easily diagnosed from the loss of color in their coats. In black cows, the loss of color gives their coats a russet or very pale shade. The wool that becomes hard, brittle, very poor in quality, and greatly reduced in yield. Pregnant ewes have pale mucous membranes, a rapid pulse, and general signs of fatigue.
Overall, affected animals are in poor general condition characterized by progressive weight loss which may develop into anemia, caused by the diarrhea (SILVA et al., 2014; SOUSA et al., 2017).

Copper deficiency has been recognized as a cause of neurologic diseases in offspring due to deficiency of this metal in their dams (SILVA et al., 2014). General clinical signs are tremors, incoordination, paralysis and death. Recently in Brazil, copper deficiency was associated with peripheral neuropathy, leading to laryngeal paralysis in adult goats, whose main characteristic is stridor when the animals are forced to move (SOUSA et 
al., 2017). Similarly, peripheral neuropathy has been described in copper-deficient moose (Alces alces) (FRANK et al., 2004) and yaks (Bos grunniens) (XIAO-YUN et al., 2006). This paper aim to report a case of peripheral neuropathy with paralysis of a hindlimb in a copper-deficient goat, and highlights the clinical, and pathological features.

An 05-years-old Toggenburg male goat was referred to the veterinary care; the main owner complaint was the paralysis of a hindlimb. The goat was coming from a farm where laryngeal paralysis due to severe copper deficiency outbreak was previously reported. The goat had low body score, hyporexia, alopecia, achromotrichia (markedly around the eyes) and in the neurologic assessment presented stiff and unbalanced gait, left hindlimb protraction, paralysis with dragging of digit and difficulty to stand up (Figure 1A, 1B and 1C). In the extensor resistance test, with the goat in upright position, there was low resistance and asymmetry of the left hindlimb in response to downward pressure. Additionally, there was a decreased of muscular

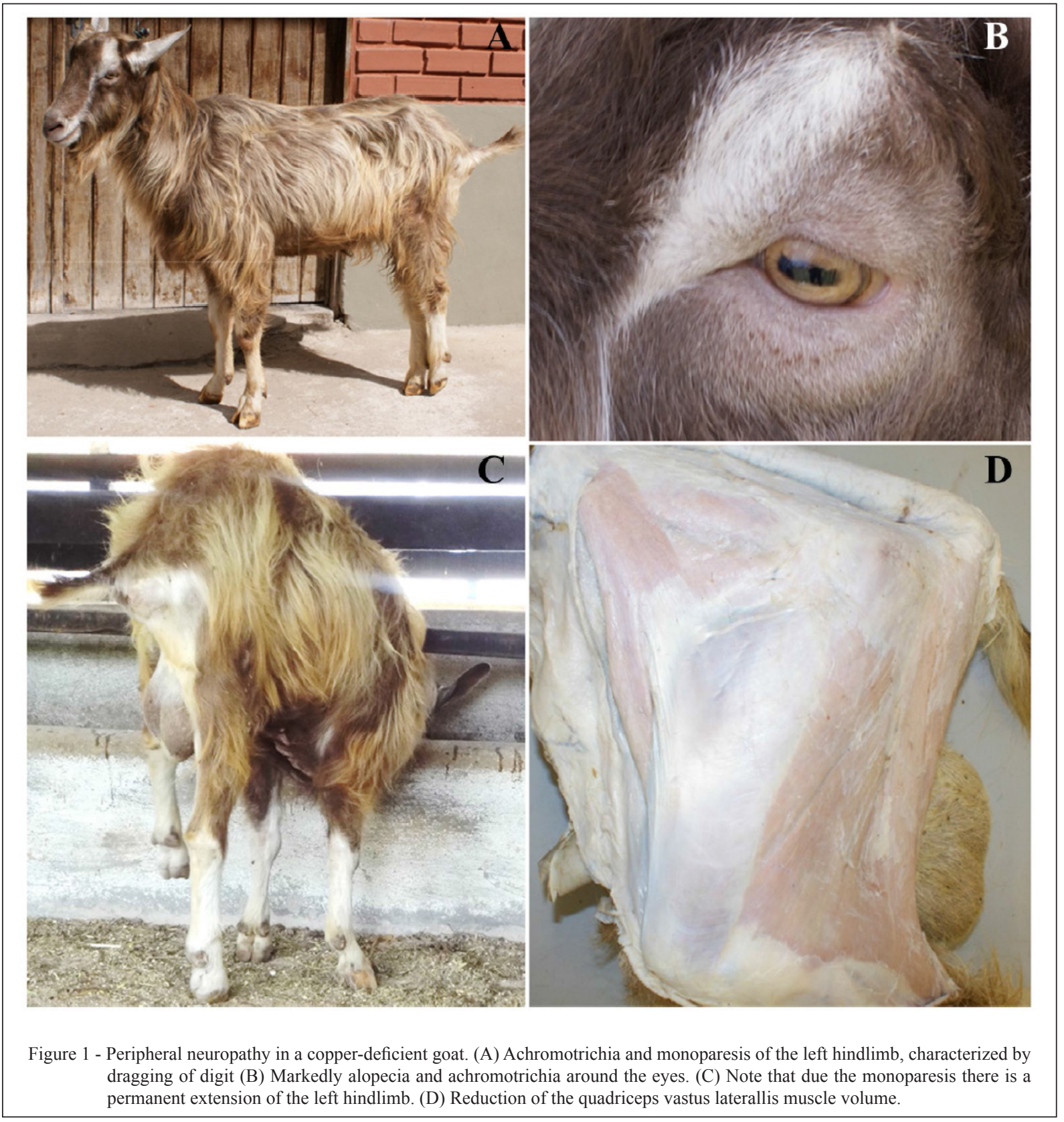

Ciência Rural, v.47, n.10, 2017. 
deep sensitivity and decreased muscular tonus of the tensor fasciae latae muscle and quadriceps femoris muscle. In the palpation, there was a reduction of the quadriceps femoris muscle volume. These symptoms developed over 90 days and started with left hindlimb claudication. The radiographic examination of the lumbar, sacrum or coccyx column was negative for trauma, neoplasia and abscess. In blood count, there was microcytic normochromic anemia, Htc $=13.8 \%$ (Reference range/RR: 22.0-38.0), $\mathrm{Hb}=3.4 \mathrm{~g} \mathrm{dL}^{-1}$ (RR: 8.0-12.0), $\mathrm{MCV}=14.1 \mathrm{fL}(16.0-25.0)$; and the copper concentration in serum was markedly lower (2.0 $\mathrm{mol} \mathrm{L}^{-1} / \mathrm{RR}$ : 9.4-23.6) whereas the iron serum content was significantly increased $\left(51.0 \mu \mathrm{mol} \mathrm{L}^{-1} /\right.$ RR: 34.6-37.4).
After spontaneous death, the goat was necropsied; the main gross alterations were the reduction of the quadriceps vastus laterallis muscle volume (Figure 1D) and focal dark red areas in the accessory and cranial lobes of the lung and in the ventral portion of the caudal lobe. There were no significant changes in the other organs examined. Fragments of CNS, spinal cord, sciatic nerve, femoral nerve, sartorius, tensor fasciae latae, quadriceps and gluteus muscle were fixed in $10 \%$ formalin, processed routinely and embedded in paraffin. Three micrometer sections of the paraffin blocks were made and stained with hematoxylin and eosin. Histologically there was atrophy of the quadriceps vastus laterallis muscle (Figure 2A).

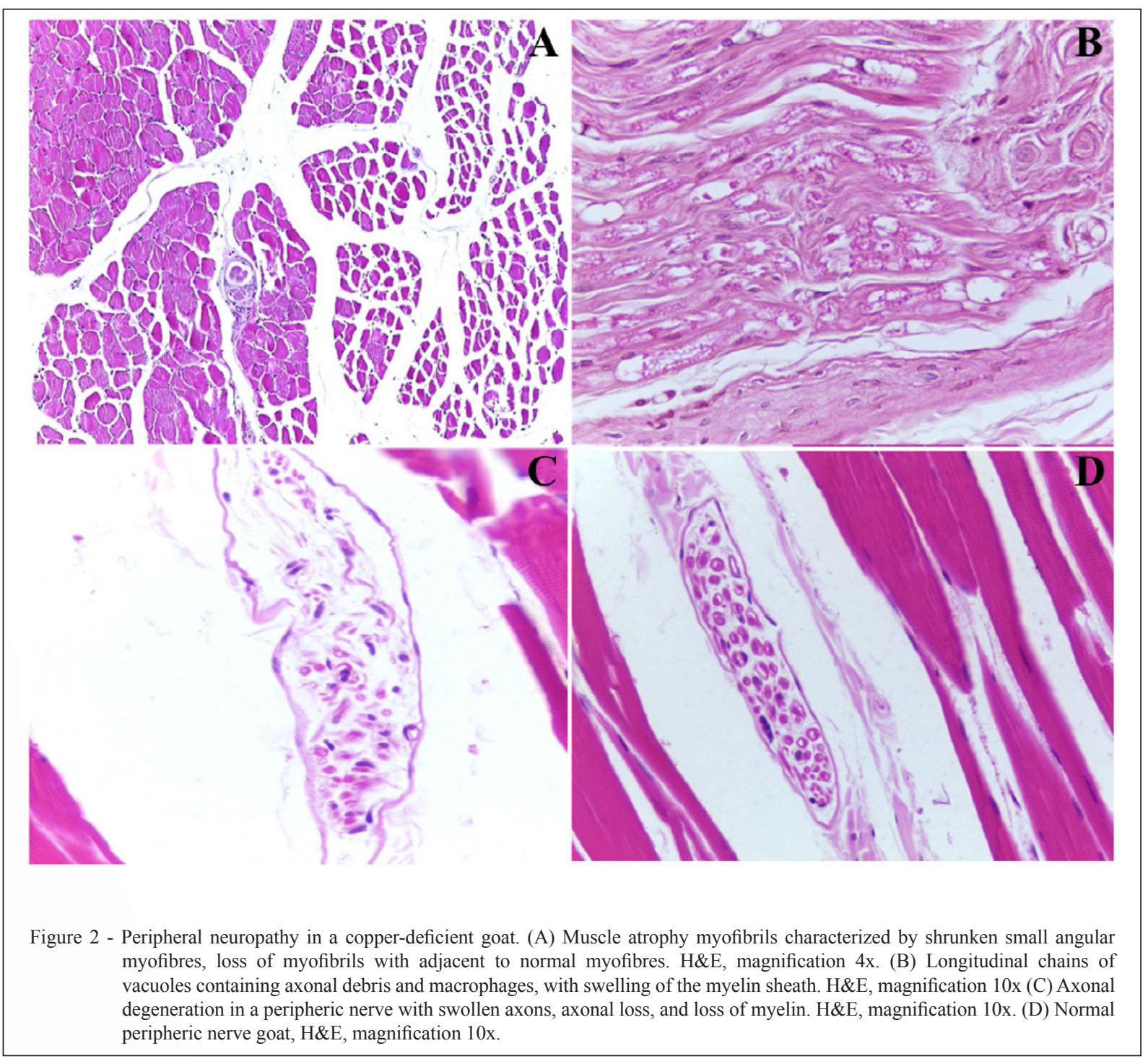

Ciência Rural, v.47, n.10, 2017. 
Atrophy was characterized by reduction in myofibre diameter with an angular contour of shrunken myofibres. Atrophic fibers were interspersed with non-atrophic fibres, without evidence of clustering, resulting in marked variation in fibre size. In this muscle, the presence of satellite cells, infiltration of lymphocytes, macrophages and replacement of the fibers by connective tissue were observed. In the femoral nerve, there was axonal degeneration with myelin sheath expansion and the presence of vacuoles, usually in chains and containing axonal debris or macrophages (Figure 2B, 2C and 2D). No lesions were observed in other CNS or PNS samples.

Peripheral neuropathies consist of injury or loss of peripheral nerves function, observed by conscious proprioceptive deficits, hypoalgesia or analgesia and hyporeflexia or areflexia of the affected limb (VAN METRE et al., 2001; DIVERS, 2004). This report described other peripheral neurologic condition related to the copper deficiency that was characterized mainly by monoparesis due to a neurogenic atrophy of an extensor muscle.

Serum copper concentration in the affected goat was lower $\left(2.0 \mu \mathrm{mol} \mathrm{\textrm {L } ^ { - 1 } )}\right.$ than those reported for goats with copper deficiency which ranges from 3 to $9 \mu \mathrm{mol} \mathrm{L} \mathrm{L}^{-1}$, and matches with the previously cases reported by our team of laryngeal paralysis in copper-deficient goats, which was $1.36 \pm 0.39 \mu \mathrm{mol}$ $\mathrm{L}^{-1}$ (SOUSA et al., 2017). A low copper content in the nervous system leads to a deficiency of COX and a decreased synthesis of phospholipids to the neurons (ZATTA \& FRANK, 2007). These are the main mechanisms of peripheral nervous system dysfunction reported in this case.

Most cases of acquired peripheral nerve disease resulted from injuries, and commonly only one limb is involved and frequently occur secondary to myopathy in recumbent adult cattle (VAN METRE et al., 2001). In small ruminants, peripheral nerve injury is less common, mainly likely due to their smaller size, but may occur from predator wounds or iatrogenically following intramuscular drug administration (DIVERS, 2004). Femoral nerve arises from the L4-L6 nerve roots and is responsible for extension of the stifle and flexion of the hip. Ruminants with femoral nerve paralysis cannot support the affected limb because of a lack of extensor tone and take on a characteristic crouched posture. In these cases, atrophy of the quadriceps femoris muscle may be noted (WAGGONER et al., 1999).

In copper-deficient ruminants, a wide variation in the clinical signs of adult animals could be observed, including anemia, weight loss, achromotrichia, alopecia, and diarrhea at the onset of clinical signs (TOKARNIA et al., 1998; SOUSA et al., 2017). Ataxia, torpor, aspiration pneumonia and stridor were just observed in the more severely copper-deficient goats (SOUSA et al., 2017). Some of these clinical signs (anemia, weight loss and achromotrichia), were observed in the goat with monoparesis. This variation in signs should be considered when diagnosing severe copper deficiency in this specie.

\section{ACKNOWLEDGEMENTS}

To the Conselho Nacional de Desenvolvimento Científico e Tecnológico (CNPq), by the Research Productivity Exchange of the author F. S. Mendonça (Process 309725/2015-1).

\section{BIOETHICS AND BIOSSECURITY COMMITTEE APPROVAL}

Animal care and procedures was approved by the ethics committee of the Universidade Federal Rural de Pernambuco (Process Number 23082.019750/2014-71).

\section{REFERENCES}

COUSINS, R.J. Absorption, transport and hepatic metabolism of copper and zinc with special reference to metallothionein and ceruloplasmin. Physiol Rev, v.65, n.2, p.238-309, 1985. Available from: <http://physrev.physiology.org/content/65/2/238.full-text. pdf + html $>$. Accessed: Apr. 05, 2017.

DIVERS, T.J. Acquired spinal cord and peripheral nerve disease. Vet Clin North Am: Food Anim Pract, v.20, n.2, p.231242, 2004. Available from: <http://europepmc.org/abstract/ med/15203224>. Accessed: Mar. 20, 2017. doi: 10.1016/j. cvfa.2004.02.008

FRANK, A. A review of the "mysterious" wasting disease in Swedish moose (Alces alces L.) related to molybdenosis and disturbances in copper metabolism. Biol Trace Elem Res, v.102, n.3, p.143-159, 2004. Available from: <https:// link.springer.com/article/10.1385\%2FBTER\%3A102\%3A13\%3A143>. Accessed: Apr. 06, 2017. doi: 10.1385/ BTER:102:1-3:143.

SILVA, T. et al. Outbreaks of copper deficiency in ruminants in the semiarid region of Paraíba, Brazil. Semina, v.35, n.4, p.19551960, 2014. Available from: <http://www.uel.br/revistas/uel/index. php/semagrarias/article/download/16872/14854>. Accessed: Mar. 30, 2017. doi: 10.5433/1679-0359.2014v35n4p1955.

SOUSA, R.F.A. et al. Laryngeal neuropathy in adult goats with copper deficiency. Vet Pathol, v.54, n.4, p.676682, 2017. Available from: <http://journals.sagepub.com/ doi/10.1177/0300985816681410>. Accessed: Apr. 06, 2017. doi: $10.1177 / 0300985816681410$.

TOKARNIA, C.H.; DÖBEREINER, J. "Ronca" a disease of unknown etiology in cattle, characterized by a snoaring respiration. Pesq Vet Bras, v.18, n.3-4, p.93-98, 1998. Available from: 
$<$ http://www.scielo.br/scielo.php?script=sci_arttext\&pid=S0100736X1998000300001>. Accessed: Apr. 05, 2017. doi: 10.1590/ S0100736X1998000300001.

VAN METRE, D.C. et al. Examination of the musculoskeletal system in recumbent cattle. Compendium, v.23, n.2, p.S5-S24, 2001. Available from: <http://assets.prod.vetlearn.com. s3.amazonaws.com/mmah/88/02160458114fb38a3e3cd569885a fc/filePV_23_02_S5.pdf >. Accessed: Mar. 20, 2017.

XIAO-YUN, S. et al. Copper deficiency in yaks on pasture in western China. Can Vet J, v.47, n.9, p.902-906, 2006. Available from: <https://www.ncbi.nlm.nih.gov/pmc/articles/PMC1555694/ pdf/cvj47pg902.pdf>. Accessed: Apr. 06, 2017.

WAGGONER, D.J.etal. The role of copper in neurodegenerative disease. Neurobiol Dis, v.6, n.4, p.221-230, 1999. Available from: <http://www. sciencedirect.com/science/article/pii/S0969996199902504>. Accessed: Apr. 06, 2017. doi: 10.1006/nbdi.1999.0250.

ZATTA, P.; FRANK, A. Copper deficiency and neurological disorders in man and animals. Brain Res Rev, v.54, n.1, p.19-33, 2007. Available from: $<$ http://www.sciencedirect.com/science/article/pii/S0165017306001147>. Accessed: Apr. 06, 2017. doi: 10.1016/j.brainresrev.2006.10.001. 